\title{
Farmer-led approaches to increasing tree diversity in fields and farmed landscapes in Ethiopia
}

\author{
Abayneh Derero (D) Richard Coe - Catherine Muthuri - Kiros M. Hadgu • \\ Fergus Sinclair
}

Received: 31 December 2019/Accepted: 29 June 2020 / Published online: 17 July 2020

(C) The Author(s) 2020

\begin{abstract}
Increasing tree cover and managing trees better on farms in Ethiopia supports livelihoods and the environment but most tree-planting schemes promote only a few species. This research aimed to understand farmers' tree planting priorities in Oromia, Ethiopia and address challenges involved in meeting them. Tree species and planting niches were elicited through focus group discussions. Participatory trials compared 17 tree species across seven on-farm planting niches and seedling survival and growth patterns were evaluated. Farmers suggested a high diversity of tree species suitable for each niche with fruit species mainly selected for homesteads. The diversity of desired tree species is much higher than that typically available in nurseries or promoted by tree planting projects. Meeting planting demands was
\end{abstract}

A. Derero $(\square)$

Ethiopian Environment and Forest Research Institute,

P. O. Box 30708, Addis Ababa, Ethiopia

e-mail: abaynehdd@yahoo.com; abaynehd@eefri.gov.et

R. Coe · C. Muthuri · F. Sinclair

World Agroforestry Centre (ICRAF),

PO Box 30677, Nairobi 00100, Kenya

K. M. Hadgu

World Agroforestry Centre (ICRAF) Ethiopia Office, c/o

ILRI-Ethiopia, P.O. Box 5689, Addis Ababa, Ethiopia

F. Sinclair

School of Natural Sciences, Bangor University, Wales, UK difficult because the existing seedling supply does not support diversity. Evaluation of tree survival showed striking differences among species, farms, agroecologies and planting niches. There was high variation in seedling survival amongst the tree species planted on $1893 \mathrm{farm} /$ planting niche locations, indicating impact of local level risk factors attributable to management, biotic and abiotic causes. Growth differences of the six shared species common to both agroecologies across different niches, showed that the effects of species and niche were significant on growth. A farmer-led approach to increasing tree cover that couples understanding of species and planting niche preferences with appropriate seedling supply and management is proposed as a means to increase the diversity of trees in farmed landscapes.

Keywords Agroecology · Farm · Food security · Homestead $\cdot$ Niche $\cdot$ Priority species

\section{Introduction}

There are multiple reasons for farmers to keep or add trees to agricultural landscapes. Incorporating trees into crop fields and agricultural landscapes may contribute to increased nutrient availability and soil enrichment (Barnes and Fagg 2003; Barrios et al. 2012; Jose 2009) coupled with maintenance of soil organic matter and structure (Akinnifesi et al. 2007; 
Chirwa et al. 2007). In addition, trees in agricultural landscapes can improve water infiltration (Carroll et al. 2004; Ilstedt et al. 2007; Sanou et al. 2010). Farmland trees can also produce fruit, fodder, fuel, fibre and timber that may increase income directly through sales or through system intensification (Nyaga et al. 2015). Increasing tree cover in agricultural landscapes can also enhance carbon storage both above- and below-ground (Makumba et al. 2007; Zomer et al. 2016) associated with production resilience in the face of climate variability (Sinclair et al. 2019). Thus, the use of trees within farming systems can increase food and nutrition security of resource-poor rural people while enhancing the provision of ecosystem services, and helping to create a climate-resilient farming landscape (Barrios et al. 2018; Kuyah et al. 2016; Steenwerth et al. 2014).

Increasing tree diversity as well as tree cover can further enhance food and nutrition security, ecosystem services and products, generating an interest in restoration of biodiversity in agricultural landscapes (Benayas and Bullock 2012). This makes better management of farm-level tree species diversity a key strategy in achieving landscape heterogeneity and biodiversity conservation (Boffa et al. 2005; Weibull et al. 2003). Increased tree species diversity can reduce pest and disease risks related to monoculture and growing only a few tree species across a landscape (Harrison et al. 2019). The use of diverse tree species in agricultural systems can also be viewed as in situ conservation of species and can provide habitat to support other biodiversity (Harvey et al. 2006). Appreciation of the within species diversity that exists amongst populations and the use of seeds or seedlings of appropriate provenances is also very important in ensuring well adapted tree species likely to grow well where they are planted (Derero et al. 2011). Thus, a wide genetic base is desirable for agroforestry tree planting initiatives (Dawson et al. 2009).

In Ethiopia, the important environmental, economic and social roles that trees play across landscapes has been threatened due to deforestation (Duguma et al. 2019) and this, coupled with severe soil loss and intensification of crop and livestock production, has resulted in severe land degradation (Taddese 2001). The depletion of tree resources has also led to shortage of wood and non-wood tree products creating an imbalance between supply and demand (Teketay 2001). Smallholders are opting largely for eucalypt woodlots and boundary planting for wood production (Getahun 2003; Lemenih and Kassa 2014), but these practices do not support biodiversity and other environmental services (Jagger et al. 2005; Kidanu et al. 2005). At the same time, increasing tree cover and diversity in crop fields and on grazing land, could enhance service and production functions (Endale et al. 2017).

Promotion and scaling up of agroforestry, broadly defined as use of trees in farmland (van Noordwijk et al. 2019) is an important strategy in natural resources management in Ethiopia, especially for the highly deforested and degraded highlands (EFAP 1994). Agroforestry is also being promoted in the wind prone lowland areas that comprise a significant portion of the country with highly degraded forest types and rangelands. In Ethiopia, trees are found and valued in multiple niches in farmland including around homesteads, in home gardens, line planting on borders, scattered trees in cropland, coffee farms and parklands, as woodlots and on rangelands (Abebe 2005; De Beenhouwer et al. 2016; Desta and Coppock 2002; Kassa et al. 2010; Poschen 1986; Tsegaye et al. 2010).

The standard practice for scaling up the use of trees on agricultural landscapes in Ethiopia has been to produce tree seedlings of a few species and distribute to farmers and to mount large tree planting campaigns. This approach has weaknesses in that it fails to match the species with farmers specific needs and interests and does not recognise the context specificity of tree preferences and expected performance. Nor does it maintain or increase the diversity of trees in farmlands. An alternative approach involves research 'in' development where scaling-up agroforestry is embedded in development initiatives so that tree planting options are tested across variation in context of farms and agricultural landscapes in a participatory cycle of planning, implementation and evaluation (Coe et al. 2014). The approach includes farmers carrying out simple comparative experiments to find out what works for them. These have sometimes been labelled 'planned comparisons' to distinguish them from the unplanned comparisons from which projects attempt to learn through monitoring and evaluation activities (Coe et al. 2017). Such an innovative approach is expected to result in higher diversity of trees adopted on agricultural lands at the same time as providing information for guiding further interventions (Sinclair and Coe 2019). 
The overall objective of the work was to develop and test an approach to discovering the tree diversity that farmers want, to test the performance of some of these tree species across farm niches in both semi-arid and sub-humid agroecologies and thereby to generate knowledge about how to effectively supply species diversity for farm planting. The approach was based on two principles:

1. Farmers understand the diversity of tree species and planting niches in which they will be of value to them.

2. Farmers can test multiple alternatives rather than simply following a fixed recommendation on what to plant, and thereby provide information for themselves, the extension system, policy makers and future planners.

\section{Materials and methods}

Site description

The work took place in locations representative of semi-arid and sub-humid zones of Ethiopia. The semiarid sites are located within the Central Rift Valley, in the East Shewa Zone with average altitude of 1600 m.a.s.l, and receive mean annual rainfall of $750-900 \mathrm{~mm}$ and have mean annual temperature of $21{ }^{\circ} \mathrm{C}$ (Endale et al. 2017). Acacia woodland and savannah being the natural vegetation type, the major crops grown in the area include teff (Eragrostis tef) and maize (Zea mays) (Endale et al. 2017). The subhumid sites are in West Shewa and East Wollega zones of Western Oromia, Ethiopia with altitude ranging from 1300 to 2200 m.a.s.l. (Samuel et al. 2019). The mean annual temperature ranges from 14 to $28{ }^{\circ} \mathrm{C}$, and the mean annual rainfall ranges from 1320 to $2000 \mathrm{~mm}$ (Samuel et al. 2019). Whereas the natural vegetation is a dry Afromontane and grassland

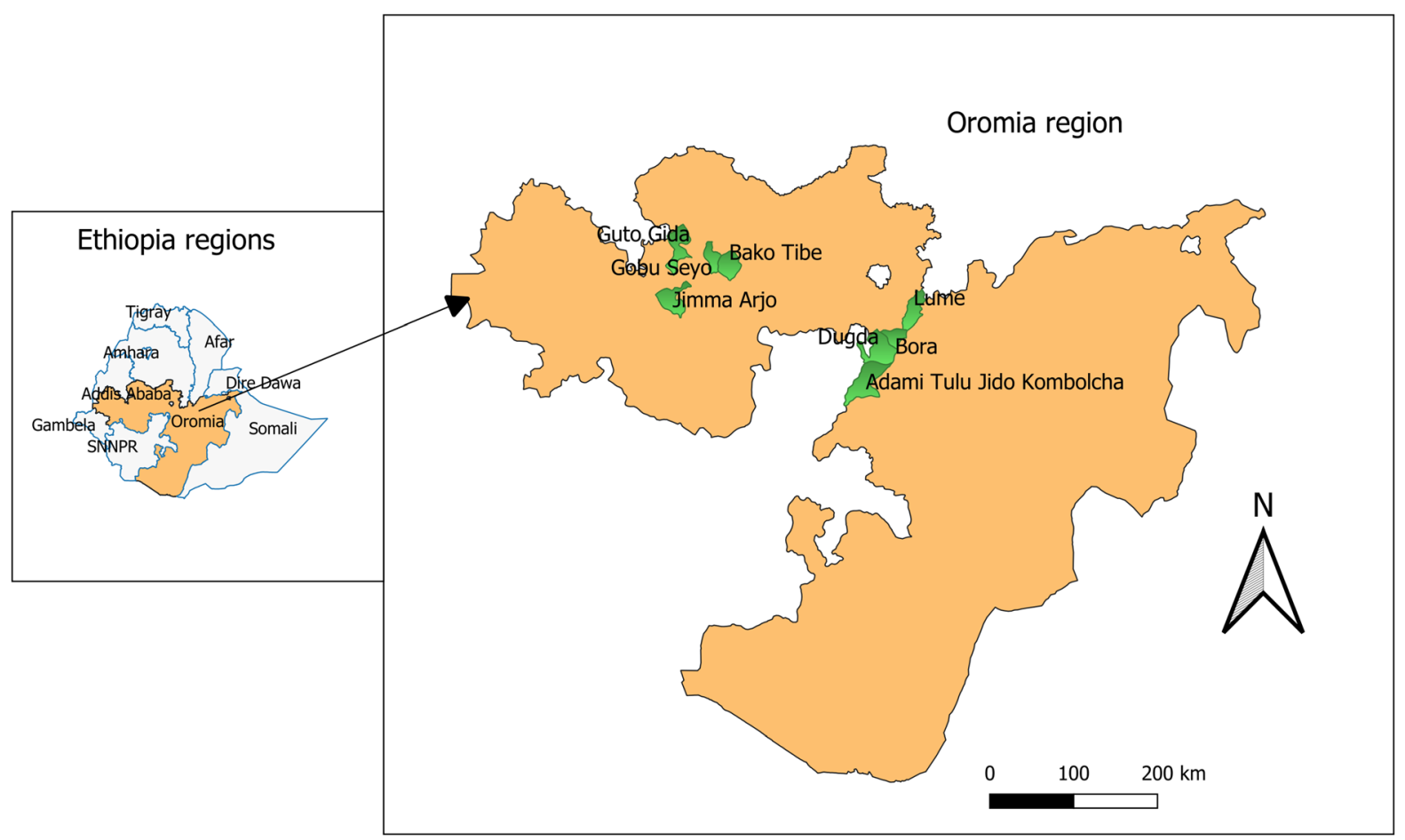

Fig. 1 Location of the project area within Ethiopia and the woredas studied 
complex type, the dominant crops grown in the area are maize, sorghum (Sorghum bicolor) and teff (Teshome 2014). The semi-arid sites were in four woreda's (districts); namely, Adami Tulu Jido Kombolcha, Dugda, Bora and Lume, whereas the subhumid sites were in four woredas, namely Jimma Arjo Guto Gida, Gobu Sayo and Bako Tibe (Fig. 1).

Farm selection and characterization

Household selection was conducted in a participatory fashion involving local extension workers ("development agents"). After sensitization meetings, farmers willing to plant trees in their homesteads, crop lands and other niches were purposively selected based on perceived convenience to implement the trials and to ensure a range of land holding sizes and other socioeconomic contexts, including varied access to water.

Identification of priority tree species and niches

A total of 24 focus group discussions, three in each site, were conducted to prioritize tree species under different planting niches. A total of 277 farmers (233 male and 44 female) participated as respondents, and a total of 33 extension workers ( 24 male and 9 female) as facilitators in the focus group discussions. The semi-arid and sub-humid groups were given 50 and 44 tree species, respectively to score and rate their preferred species for planting. The list of the candidate species was prepared based on: (1) former exercises on farmers' priorities, and (2) data from a survey on tree species produced in various nurseries in the eight woreda's (Dedefo et al. 2017). Each group was given an assignment of prioritizing tree species for planting under different niches by scoring each species on a scale from 1 to 5 . Species were given a score of from 1 (lowest priority) to 5 (highest priority), or zero (not mentioned for that niche).

Tree planting and establishment of participatory trials

Participatory trials were established in four semi-arid and another four sub-humid areas. The steps in the participatory trial process involved (1) setting the research agenda and questions, (2) defining the approach, (3) working out details for implementation, (4) implementing trials, (5) data collection and interpretation and (6) follow up for joint planning of next steps. The tree species considered in the participatory trials included fruit trees and other multipurpose tree species. The participatory trials were established in July-August 2014 under different niches with different tree species. Seedlings were planted under various niches: homestead, crop land, boundary, soil bund, coffee shade and small-scale plantation with individual farmers deciding on species niche matching.

Data collection

Tree seedling survival count was conducted 1 year after establishments of the participatory trials. Height and diameter at breast height (dbh) were collected at the third year after planting. Trees that did not reach a dbh height during the time of data collection were considered as missing data.

Data analysis

Descriptive statistics were computed for tree species and planting niche priorities, seedling survival and tree growth. Counts of the number of groups that mentioned each species for each niche were tabulated ("Appendix"). Species given scores of 4 or 5 by more than $50 \%$ of the groups were identified as the highest priorities. When analysing species growth performance for each agroecology and for each niche, those represented by less than three individual trees for a given category were excluded from further analysis. Data on seedling survival was analysed using a binomial general linear model $(\mathrm{glm})$. Growth data (dbh and height) were analysed in a linear mixed model taking agroecology, species and niche as fixed effects, and sites within agroecologies as random effects. Only the six species which were shared between the sub-humid and the semi-arid agroecologies and with at least 10 observations per agroecology or niche, were considered for the growth analysis. When needed, the Tukey HSD mean separation technique was employed for mean separation in cases of statistically significant differences. 
Table 1 List of niches (land use categories) and their scores in semi-arid and sub-humid agroecologies
NA not applicable i.e. not included in the semi-arid list as it is not a coffeegrowing area

\begin{tabular}{llll}
\hline No. & Niches & \multicolumn{2}{c}{ Mean score out of five } \\
\cline { 3 - 4 } & & Semi-arid & Sub-humid \\
\hline 1 & Homestead & 5 & 4.5 \\
2 & Soil bund/terrace & 2.5 & 4.8 \\
3 & Crop field & 2.9 & 4.4 \\
4 & Boundary & 3.3 & 3.5 \\
5 & Communal land & 2.7 & 2.2 \\
6 & Plantation (woodlot, fodder bank, fruit orchard) & 4.3 & 3.9 \\
7 & Coffee shade & NA & 3.6 \\
\hline
\end{tabular}

\section{Results}

Farmers' preferred tree species and planting niches

From the focus group discussions (FGDs), it was learnt that farmers were interested in planting diverse tree species in diverse niches. During the FGDs, it was documented that farmers consider the following criteria in making tree planting decisions: (1) availability of space and the already available tree stock and its composition; (2) ease of tree protection and care after planting; (3) the challenges that free grazing poses to seedling survival and growth; and (4) potential conflict with neighbours. The scores in the sub-humid agroecology showed that soil bunds, homestead and crop land (intercropping outside of soil bunds) were the three highest priority niches, and in the semi-arid agroecology, homesteads and plantations were given the highest scores (Table 1).

Priority tree species in semi-arid areas

A diverse range of priority tree species were mentioned for different niches. Species that were mentioned often ( $>50 \%$ of the cases) were many, with the lowest (10 species) recorded for crop lands. Species accorded a high score (4 or 5, 'good') and hence considered particularly suitable for each niche but regardless of the frequency of mention, were also diverse, with crop land again having the lowest diversity with mention of only 30 species. Species rated as 'good' often ( $>50 \%$ of the cases) were less in number and ranged from 1 for the soil bunds to 19 for homesteads and at least five species for the other niches (Table 2).
Priority tree species in sub-humid areas

A slightly lower diversity of priority tree species were mentioned for different niches in the sub-humid areas than in the semi-arid area. Species that were mentioned often ( $>50 \%$ of the cases) were many, with the lowest diversity recorded for coffee shade with only 6 species. Across all niches, the number of species mentioned as 'good' (score of 4 or 5) was distinctly lower than the number at the semi-arid site, but there were still many species mentioned. Species rated as 'good' often ( $>50 \%$ of cases) were few ( 2 to 4 ) for all niches except homesteads where 10 species were mentioned. Nine priority species in the homesteads were fruit trees, with the tenth being coffee (Table 3 ).

The PCA biplot (Fig. 2a, b) showed that in both the semi-arid and the sub-humid sites, the fruit species cluster (circled) were mainly selected for homesteads. Generally, the two agroecologies had distinct priorities (Fig. 3). The six tree species in the top right that had high preference score in both ecozones were Sesbania sesban, Grevillea robusta, Cordia africana, Leucaena leucacephala, Croton machrostachyus and Casuarina equisetifolia.

Linking priorities to actual planting and survival

Figure $4 a, b$ summarises the status of each species and niche in terms of farmers' priorities, numbers planted and survival rate. A total of 17 different tree species were planted. The actual planting didn't fully reflect priorities as the seedling production and planting mainly depended on the tree seeds that could be availed from nurseries or the fruit tree seedlings that could be procured and availed during planting time. Thus, some lower priority trees were planted, whereas some high priority trees were not (Fig. 4a, b). 
Table 2 Farmers' most preferred species for planting under different niches in the semi-arid sites in Oromia, Ethiopia

\begin{tabular}{|c|c|c|c|c|c|c|}
\hline No. & Boundary & Communal & Crop land & Homestead & Plantation & Soil bund \\
\hline 1 & $\begin{array}{l}\text { Faidherbia } \\
\text { albida }\end{array}$ & Croton macrostachyus & $\begin{array}{l}\text { Faidherbia } \\
\text { albida }\end{array}$ & Mangifera indica & Carica papaya & $\begin{array}{c}\text { Sesbania } \\
\text { sesban }\end{array}$ \\
\hline 2 & $\begin{array}{l}\text { Euphorbia } \\
\text { tirucalli }\end{array}$ & Grevillea robusta & Grevillea robusta & Coffea arabica & Rhamnus prinoides & \\
\hline 3 & $\begin{array}{l}\text { Moringa } \\
\quad \text { stenopetala }\end{array}$ & Ehretia cymosa & Cordia africana & Psidium guajava & Mangifera indica & \\
\hline 4 & $\begin{array}{l}\text { Cordia } \\
\text { africana }\end{array}$ & $\begin{array}{l}\text { Olea europaea subsp. } \\
\text { cuspidata }\end{array}$ & $\begin{array}{l}\text { Leucaena } \\
\text { leucocephala }\end{array}$ & Persia americana & Coffea arabica & \\
\hline 5 & $\begin{array}{l}\text { Dovyalis } \\
\text { abyssinica }\end{array}$ & Dodonaea viscosa & Sesbania sesban & Carica papaya & Persia americana & \\
\hline 6 & Dovyalis caffra & Acacia tortilis & & Moringa stenopetala & Citrus aurantiifolia & \\
\hline 7 & & Faidherbia albida & & Cupressus lusitanica & Cordia africana & \\
\hline 8 & & Cordia africana & & Citrus sinensis & Musa acuminata & \\
\hline 9 & & Azadirachta indica & & Rhamnus prinoides & Psidium guajava & \\
\hline 10 & & Schinus molle & & Citrus aurantifolia & Citrus sinensis & \\
\hline 11 & & Moringa stenopetala & & Cordia africana & $\begin{array}{l}\text { Moringa } \\
\text { stenopetala }\end{array}$ & \\
\hline 12 & & Leucaena leucocephala & & Ehretia cymosa & Vitis vinifera & \\
\hline 13 & & Ziziphus spina-christi & & $\begin{array}{l}\text { Olea europaea subsp. } \\
\text { cuspidata }\end{array}$ & $\begin{array}{l}\text { Eucalyptus } \\
\text { camaldulensis }\end{array}$ & \\
\hline 14 & & Grewia bicolour & & Azadirachta indica & Prunus persica & \\
\hline 15 & & $\begin{array}{l}\text { Eucalyptus } \\
\text { camaldulensis }\end{array}$ & & Vitis vinifera & Casimiroa edulis & \\
\hline 16 & & & & Musa acuminata & Grevillea robusta & \\
\hline 17 & & & & Grewia bicolour & $\begin{array}{l}\text { Dovyalis } \\
\text { abyssinica }\end{array}$ & \\
\hline 18 & & & & $\begin{array}{l}\text { Eucalyptus } \\
\text { camaldulensis }\end{array}$ & & \\
\hline 19 & & & & Delonix regia & & \\
\hline
\end{tabular}

All species frequently ( $>50 \%$ of cases) identified as good (score 4 or 5 ) in each niche

Differential survival between species and niches meant that the connection between desired and realised tree diversity was further reduced. The overall mean survival of the seedlings in both agroecologies was $45.6( \pm 32.6)$ at 6 months and $33.6( \pm 25.5) \%$ at 14 months. The 6-month survival values of each species are shown in Table 4, and values for the different species ranged from 0 to $100 \%$ in different farms/niches.

While farmers express preferences, they are interested in planting a diversity of tree species on their farm-up to 10 species in some cases.
Growth of seedlings at various agroecologies and niches

The mean height of trees in semi-arid areas $(n=733)$ was $2.8( \pm 1.4) \mathrm{m}$, whereas it was $2.8( \pm 1.7) \mathrm{m}$ in the sub-humid sites $(\mathrm{n}=2582)$ ("Appendix"). Growth differences of the shared species between the semiarid and the sub-humid sites (namely, C. africana, $G$. robusta, Jacaranda mimosifolia, Leucaena leucocephala, Moringa stenopetala and S. sesban) under the different niches showed that the effects of species and niche were significant $(p<0.001)$ both on height and dbh. The two major species, G. robusta and $S$. sesban attained their highest mean height in the sub- 
Table 3 Farmers' most preferred species for planting under different niches in the sub-humid sites in Oromia, Ethiopia

\begin{tabular}{|c|c|c|c|c|c|c|c|}
\hline No. & Boundary & Coffee & Communal & Crop land & Homestead & Plantation & Soil bund \\
\hline 1 & $\begin{array}{l}\text { Casuarina } \\
\text { equsetifolia }\end{array}$ & $\begin{array}{l}\text { Acacia } \\
\quad \text { abyssinica }\end{array}$ & $\begin{array}{l}\text { Eucalyptus } \\
\quad \text { camaldulensis }\end{array}$ & $\begin{array}{l}\text { Coffea } \\
\quad \text { arabica }\end{array}$ & $\begin{array}{l}\text { Musa } \\
\quad \text { acuminata }\end{array}$ & $\begin{array}{r}\text { Grevillea } \\
\text { robusta }\end{array}$ & Cajanus cajan \\
\hline 2 & $\begin{array}{r}\text { Grevillea } \\
\text { robusta }\end{array}$ & $\begin{array}{l}\text { Albizia } \\
\quad \text { gummifera }\end{array}$ & $\begin{array}{l}\text { Eucalyptus } \\
\text { globulus }\end{array}$ & $\begin{array}{l}\text { Cordia } \\
\text { africana }\end{array}$ & $\begin{array}{l}\text { Carica } \\
\text { papaya }\end{array}$ & $\begin{array}{l}\text { Jacaranda } \\
\quad \text { mimosifolia }\end{array}$ & $\begin{array}{l}\text { Leucaena } \\
\quad \text { leucocephala }\end{array}$ \\
\hline 3 & Sesbania sesban & $\begin{array}{l}\text { Sesbania } \\
\text { sesban }\end{array}$ & Grevillea robusta & $\begin{array}{r}\text { Grevillea } \\
\text { robusta }\end{array}$ & Catha edulis & & Sesbania sesban \\
\hline 4 & & & Spathodea nilotica & $\begin{array}{l}\text { Sesbania } \\
\text { sesban }\end{array}$ & $\begin{array}{l}\text { Citrus } \\
\text { sinensis }\end{array}$ & & \\
\hline 5 & & & & & $\begin{array}{l}\text { Coffea } \\
\quad \text { arabica }\end{array}$ & & \\
\hline 6 & & & & & $\begin{array}{l}\text { Prunus } \\
\text { persica }\end{array}$ & & \\
\hline 7 & & & & & $\begin{array}{l}\text { Malus } \\
\quad \text { domestica }\end{array}$ & & \\
\hline 8 & & & & & $\begin{array}{l}\text { Mangifera } \\
\text { indica }\end{array}$ & & \\
\hline 9 & & & & & $\begin{array}{l}\text { Persea } \\
\quad \text { americana }\end{array}$ & & \\
\hline 10 & & & & & $\begin{array}{l}\text { Psidium } \\
\text { guajava }\end{array}$ & & \\
\hline
\end{tabular}

All species frequently ( $>50 \%$ of cases) identified as good (score 4 or 5 ) in each niche

humid homesteads and their lowest mean height in the semi-arid boundary plantings (Fig. 5). The highest mean dbh was attained by $M$. stenopetala in subhumid homesteads, and it also exhibited the greatest variability in size (Fig. 6).

\section{Discussion}

Farmers' preferred tree species and planting niches

The prioritization exercise on tree species and planting niches clearly revealed that farmers in Ethiopia have an interest in high species diversity across distinct planting niches consistent with recent findings from Central and West Africa (Dumont et al. 2014, 2019a). It is also clear that the tree diversity desired by farmers is rarely available for planting either in Ethiopia or in other African contexts and often tree planting projects promote only a few species consistent with what is readily available in nurseries (Dumont et al. 2019b). Behaviour change in both projects and nurseries would be required for a diversity of tree species to be promoted for matching to the fine scale ecological differences and farmer circumstances encountered in Ethiopia (Iiyama et al. 2017). If tree planting initiatives fail to respond to the diversity needs of farmers, then (a) they will not be meeting farmers' needs and interests and (b) landscape-level tree species diversity will be much less than it could be. Farmers' interests in planting diverse tree species is due to the different values they attach to and the utilities they obtain from the different tree species, and often farmers associate a species with a primary and a secondary utility (Iiyama et al. 2017). But farmers' preference for planting a given species and the diverse tree species in general is influenced by their perception of planting space availability, existing stock and composition on their land holdings. Interventions to diversify tree seedlings produced in nurseries, which currently deal with only about seven species on average in the woredas where the participatory trials were conducted (Dedefo et al. 2017), will be needed to meet farmers' needs. Data from a national survey on tree nurseries (particularly the Oromia region data) (Lilles $\varnothing$ and Derero 2019) and that of (Dedefo et al. 2017) together show that some of 

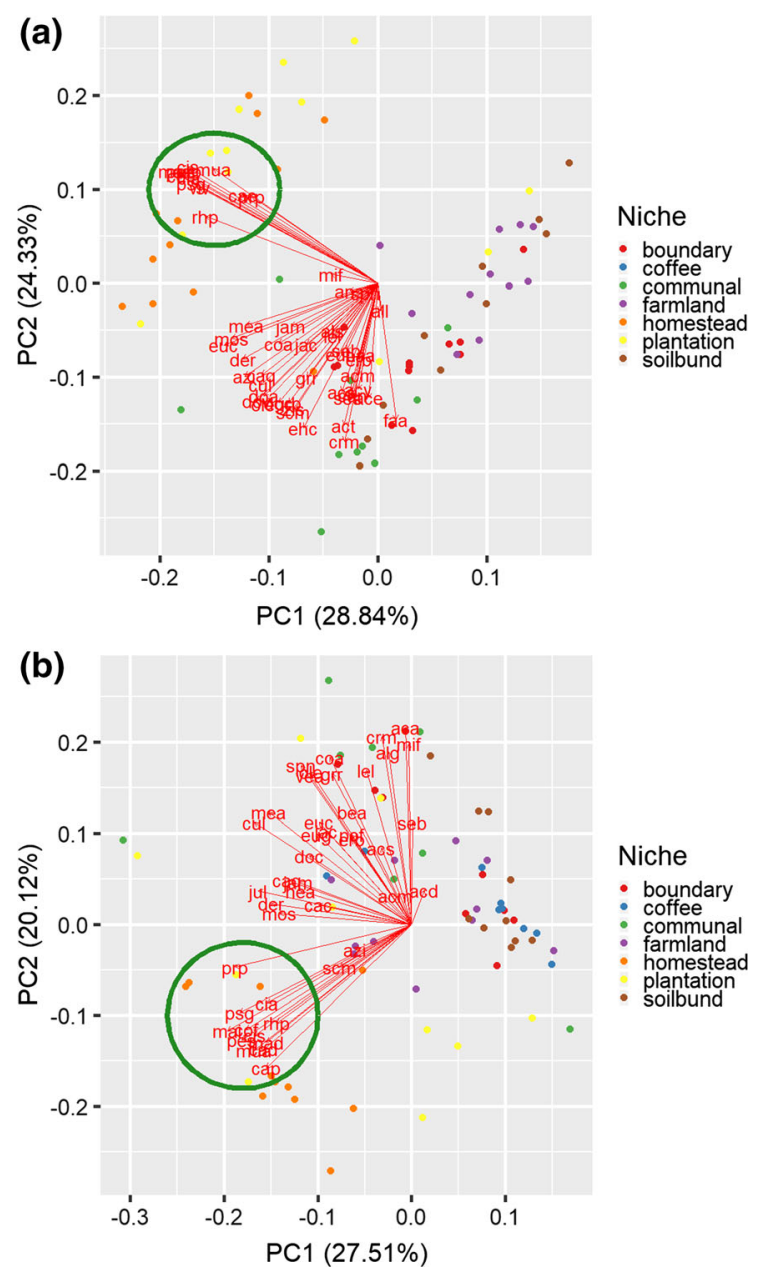

Fig. 2 Principal component analysis biplot of species priority patterns in study woredas of the semi-arid a and sub-humid, b Oromia. species codes are those in "Appendix"

the farmers' priority species were not available in nurseries (e.g. Ehretia cymosa, Ziziphus spp., and Grewia bicolour) and fruit trees such as Citrus sinensis and Citrus aurantiifolia were not commonly available to farmers. Generally, there is a shortfall in supply of tree seeds and seedlings of appropriate species to satisfy demand from farmers (Lillesø et al. 2018; Nyoka et al. 2015). Niche preference also relates to ease of protecting and caring for planted seedlings, the challenges that may come from free grazing livestock and the potential conflict that may arise with neighbours, especially in relation to boundary plantings.

The scores in the sub-humid agroecology showed that soil bund, homestead and crop land (outside of soil bunds) were the three highest priority niches with

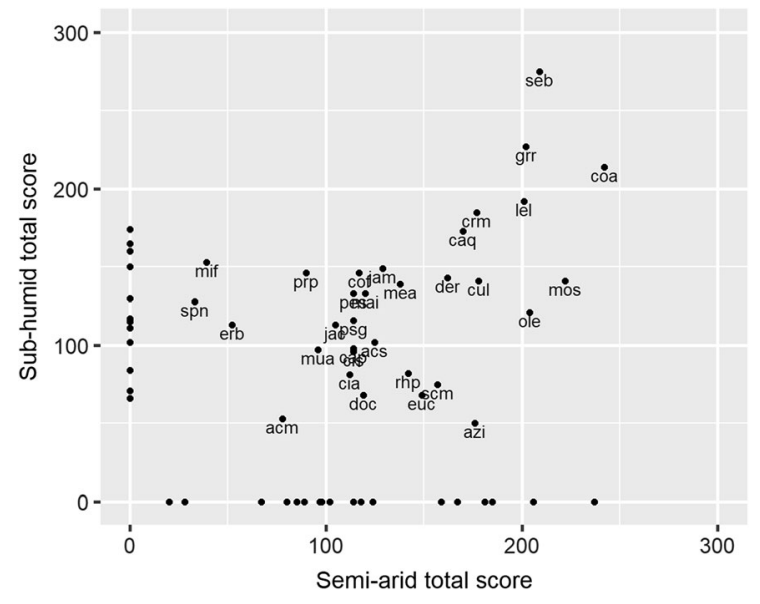

Fig. 3 Scatter plot of the total scores for species priorities in semi-arid and sub-humid woredas of Oromia. species codes are those in "Appendix". Points plotted along

above average scores, and in the semi-arid agroecology, only homestead had the highest rank with above average scores. The results imply that the sub-humid farmers had stronger interest to plant in more niches than the semi-arid farmers. This prioritization helps to decide which tree planting niches to focus on when planning scaling up activities. It can be argued that prioritization of tree species for different tree planting niches is important for niche compatibility in agroforestry and that farmers have good knowledge of matching species with niches (German et al. 2006). More diverse ranges of tree species were mentioned for all niches in the semi-arid areas than in the subhumid sites probably because the farmers in the semiarid areas had a stronger desire to integrate more trees in their farmlands. While mean tree density in semiarid croplands (19 trees ha ${ }^{-1}$ ) and grazing lands (115 trees $\mathrm{ha}^{-1}$ ) that have been reported (Endale et al. 2017) are similar to those (18 and 112 trees $\mathrm{ha}^{-1}$, respectively) reported in sub-humid areas (Samuel et al. 2019) densities in homesteads were much higher in the sub-humid (801 trees $\mathrm{ha}^{-1}$ ) than the semi-arid (132 trees $\mathrm{ha}^{-1}$ ) areas.

In both the semi-arid and the sub-humid sites, the fruit species were mainly selected for homestead planting. One addition to homesteads was coffee in the sub-humid zones. This is evidently because farmers attach very high values to fruit trees and coffee and because they could more closely protect and manage these trees in homesteads than elsewhere in their farmlands, consistent with what has been reported 
(a)

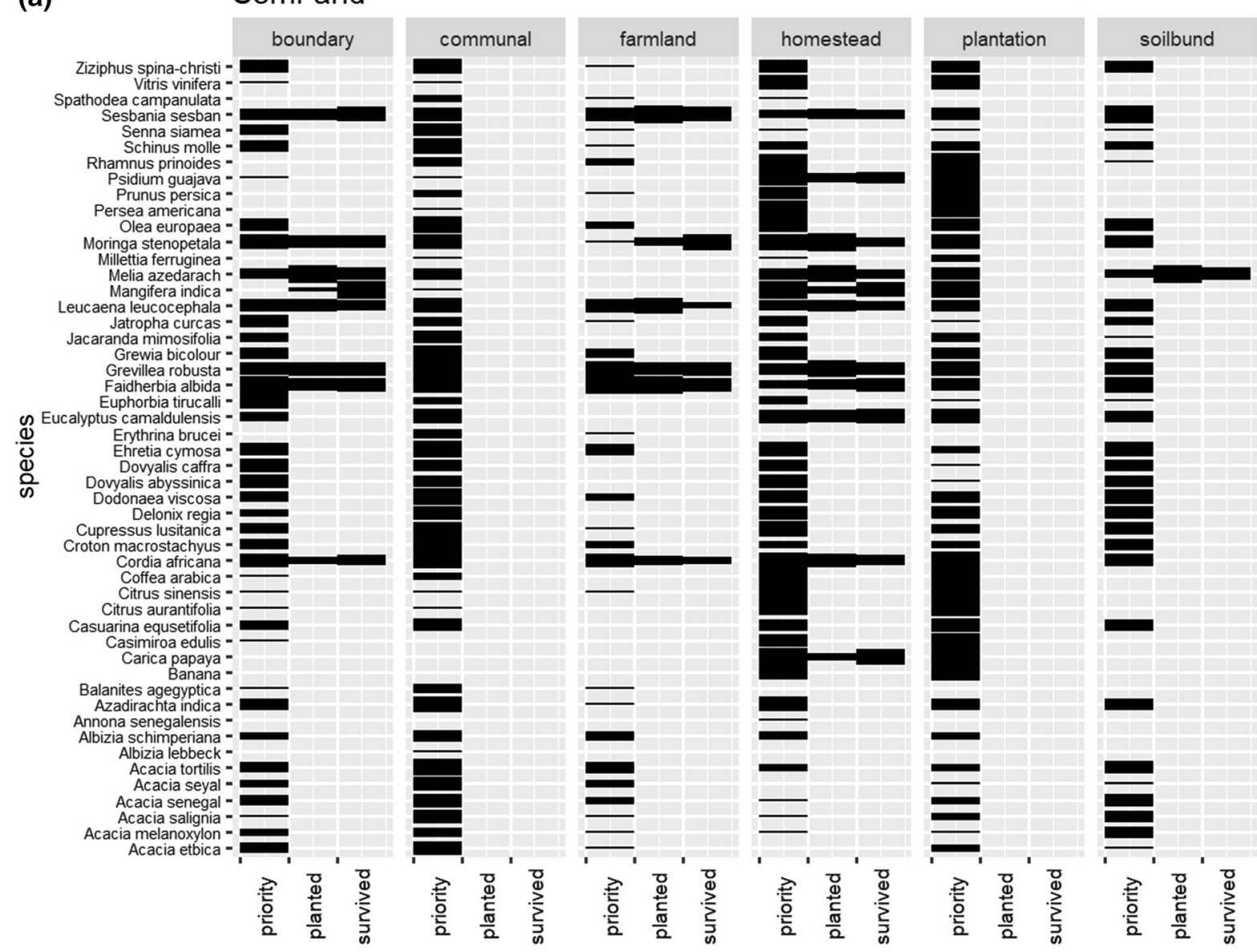

(b)

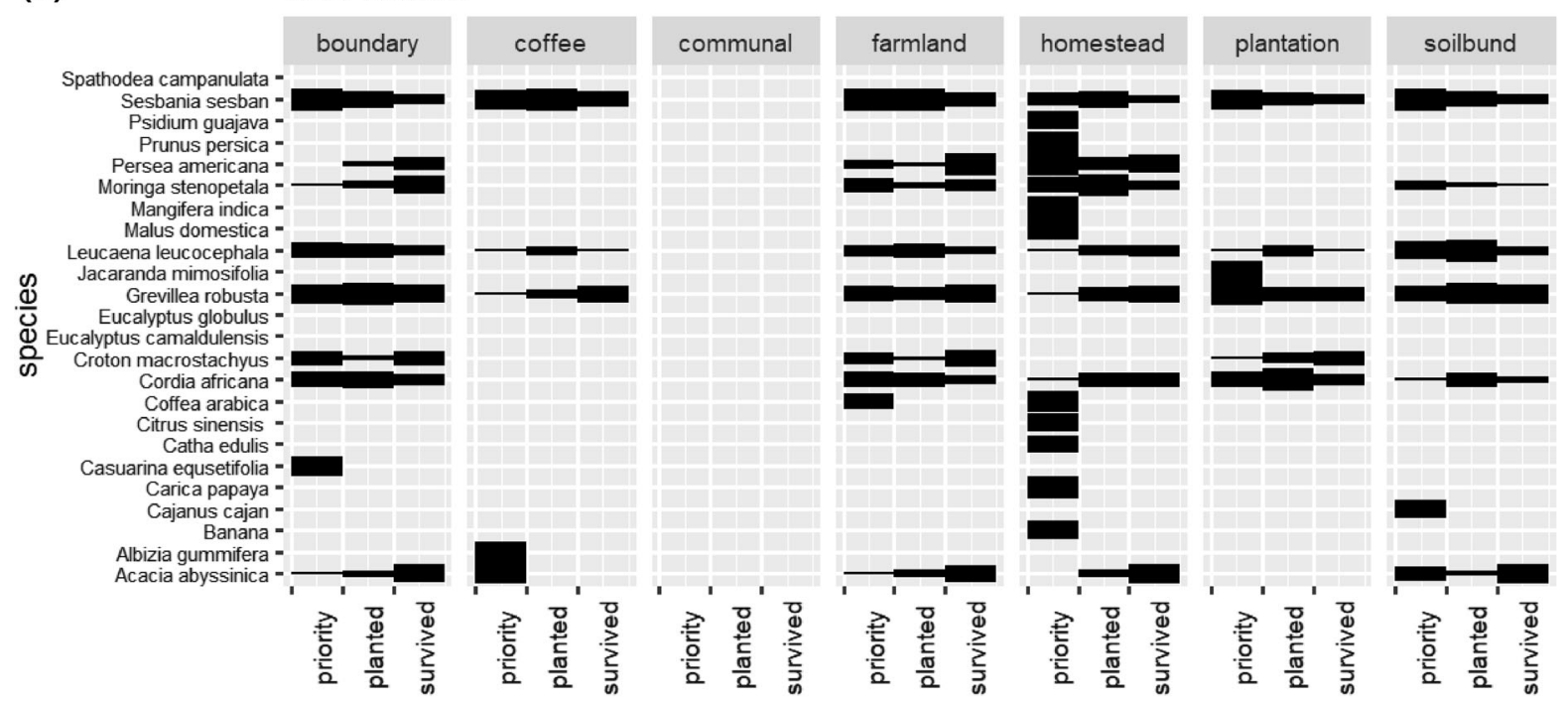

Fig. 4 Species priorities, trees planted and surviving in on-farm niches in semi-arid (a) and sub-humid woredas (b) of Oromia. Line width is proportional to priority, numbers 
Table 4 Survival values of different tree species six months after planting

\begin{tabular}{|c|c|c|c|c|c|}
\hline \multirow[t]{2}{*}{ No. } & \multirow[t]{2}{*}{ Tree species } & \multirow[t]{2}{*}{ No. of farms/niches } & \multicolumn{3}{|c|}{ Survival \% } \\
\hline & & & Range & Mean & Standard deviation \\
\hline 1 & Acacia abyssinica & 71 & $8-100$ & 65.9 & 24.8 \\
\hline 2 & Albizia schimperiana & 46 & $0-100$ & 63.0 & 37.5 \\
\hline 3 & Carica papaya & 23 & $0-100$ & 74.1 & 28.6 \\
\hline 4 & Cordia africana & 197 & $0-100$ & 30.1 & 28.0 \\
\hline 5 & Croton macrostachyus & 5 & $13-60$ & 41.3 & 17.9 \\
\hline 6 & Eucalyptus camaldulensis & 38 & $30-100$ & 72.3 & 13.9 \\
\hline 7 & Faidherbia albida & 102 & $0-100$ & 53.2 & 27.9 \\
\hline 8 & Grevillea robusta & 311 & $0-100$ & 57.2 & 28.4 \\
\hline 9 & Leucaena leucocephala & 164 & $0-100$ & 25.4 & 27.7 \\
\hline 10 & Mangifera indica & 77 & $0-100$ & 66.9 & 30.3 \\
\hline 11 & Melia azedarach & 150 & $0-100$ & 40.6 & 25.8 \\
\hline 12 & Millettia feruginea & 129 & $0-100$ & 38.2 & 32.3 \\
\hline 13 & Moringa stenopetala & 212 & $0-100$ & 29.0 & 28.4 \\
\hline 14 & Persea americana & 107 & $0-100$ & 73.6 & 31.4 \\
\hline 15 & Psidium guajava & 43 & $0-100$ & 40.0 & 24.1 \\
\hline 16 & Sesbania sesban & 194 & $0-100$ & 35.5 & 29.5 \\
\hline \multirow[t]{2}{*}{17} & Dovyalis caffra & 24 & $50-100$ & 86.1 & 16.1 \\
\hline & Total & 1893 & $0-100$ & 45.6 & 32.6 \\
\hline
\end{tabular}

from elsewhere in the Ethiopian highlands (Amede and Taye 2015). Support for farmers to create homegardens where they can grow fruit trees, coffee and vegetables could be expected to improve food security of smallholder farmers. The ecological and socioeconomic sustainability of homegardens such as the traditional enset-coffee homegarden agroforestry systems in Ethiopia has been well documented (Abebe et al. 2010).

The six species that have high overall preference score in both ecozones across several niches were $S$. sesban, G. robusta, C. africana, L. leucacephala, C. machrostachyus and C. equisetifolia. Sesbania sesban and the L. leucocephala are often promoted as fodder species, whereas G. robusta and C. africana are valued for their timber, C. machrostachyus is valued for its role in soil amelioration and $C$. equisetifolia as an ornamental tree, but these species are generally valued for the multiple benefits they provide. Thus, nurseries should produce large volumes of these species as they are likely to be in high demand by many farmers. Other species such as eucalypts may not be suitable for planting in most niches but are planted in high numbers in the form of woodlots. Therefore, detailed planning is needed to decide on quantity of seedling production of different species annually considering the niches and species that farmers want to plant.

Survival and growth of seedlings at various agroecologies and niches

The fact that the overall seedling survival (seedlings that did not die before reaching 1 year old) was about $34 \%$ indicating that much remains to be done to improve this. Seedling survival is a function of seedling quality, species-site matching, proper planting at the right time, plant density (Bell et al. 2006), herbivory and disturbance (Bekele 2005; Boerner and Brinkman 1996), edaphic conditions (Reubens et al. 2009), seasonal precipitation patterns (Boerner and Brinkman 1996), watering in dry seasons, and ability to minimize mortality due to insect pests. Results revealed high variability in fruit tree seedling survival in homesteads among farmers, suggesting that farmerto-farmer exchange of innovative ideas to protect and care for young fruit trees could improve overall performance (Sinclair and Coe 2019). In other niches, farmers preferred timber, fodder and fertilizer trees where the challenge for tree survival is exacerbated when watering is not possible, and cattle freely roam 


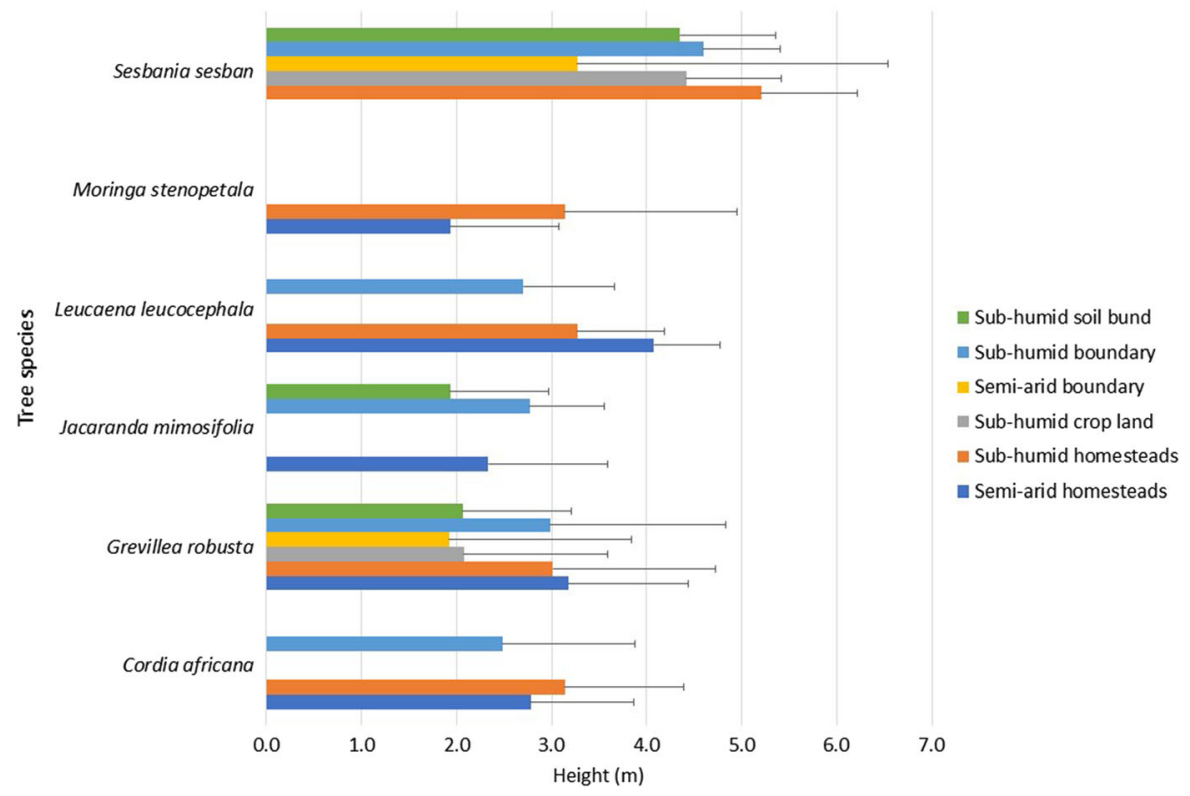

Fig. 5 Mean height attained by the shared species in the sub-humid and semi-arid sites under different niches at the third year after planting

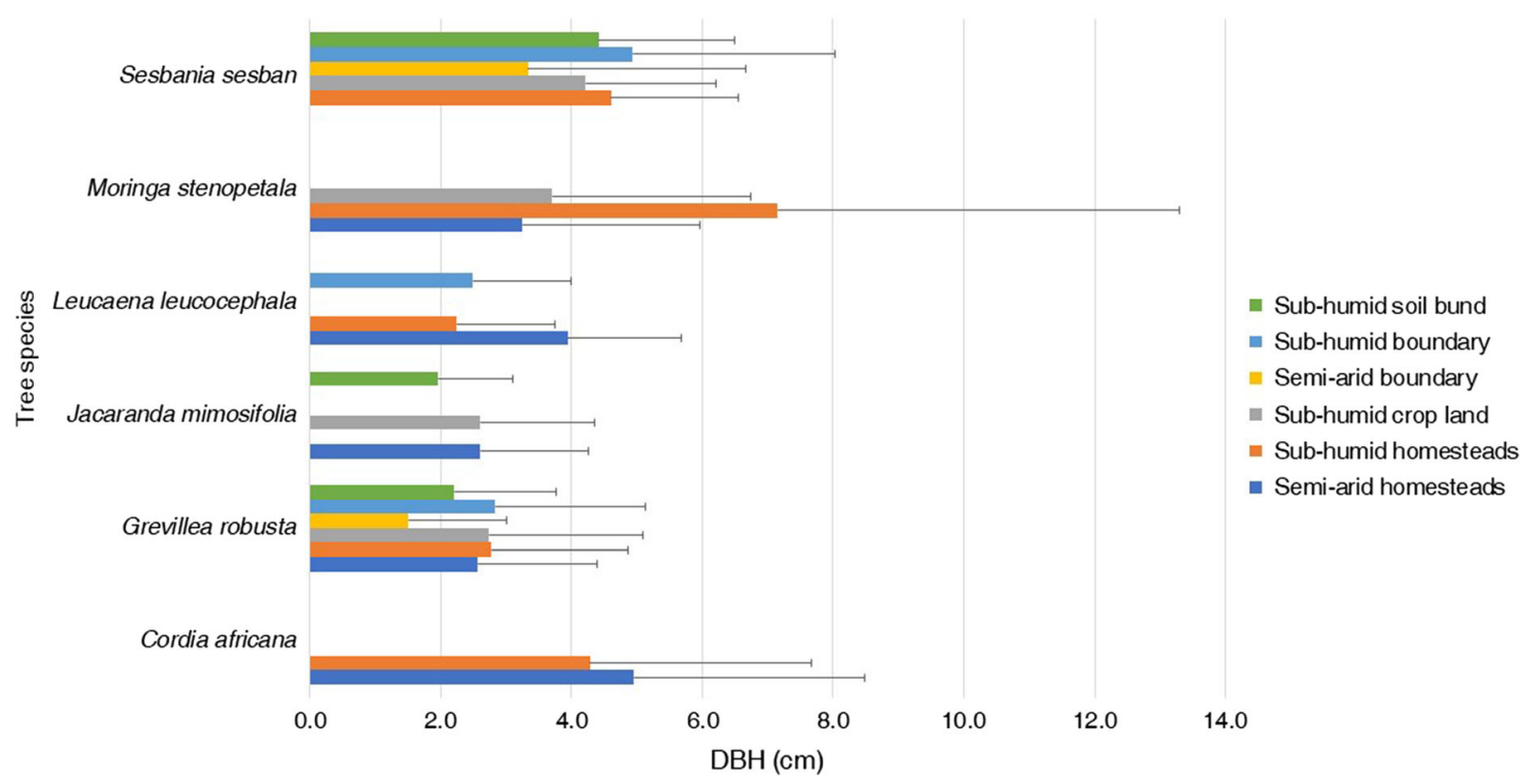

Fig. 6 DBH attained by the shared species in the sub-humid and semi-arid sites under different niches at the third year after planting

and browse the planted seedlings. Options to improve seedling protection through fencing individual seedlings and community bylaws need to be put in place to increase seedling survival in the niches outside homesteads areas. Without such interventions, landscapes will be dominated by a few species that are not susceptible to browsing damage such as eucalypts. 


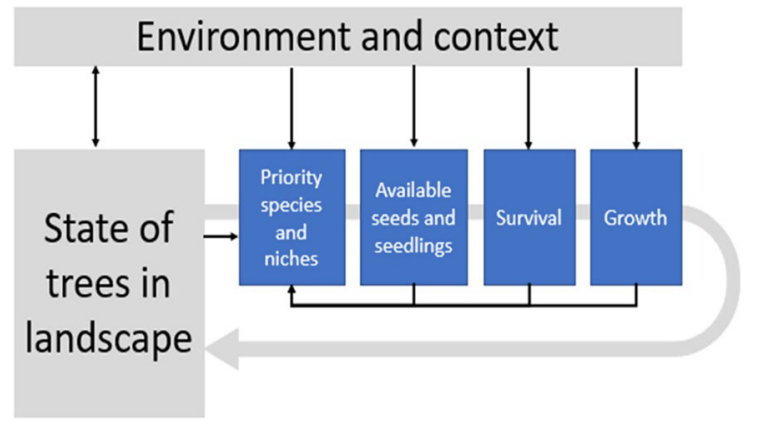

Fig. 7 Conceptual framework for an integrated farmer-led approach to increase tree cover and diversity on farms, showing change in tree cover (grey arrow), filters (blue). (Color figure online)

Seedling survival exhibited large differences between species and niche. This means that species have different responses to the different stresses they face. Despite all the confounding factors, results may be indicative of the most appropriate tree species for the agroecologies under consideration in assuring success of tree planting. Since planting niches have also showed differences in survival, the recommendations have to do with matching species with planting niches or sites. Differential survival between species and niches meant that the connection between desired and realised tree diversity was further reduced beyond the lack of availability of species from nurseries. The variation in survival rate across farms highlights the complexity of tree survival and the potential for learning about it from this sort of trial that involves many farmers. The average survival rates quoted above hide the fact that, for many species, some farmers see survival near $100 \%$ while for others most trees die, highlighting the potential for farmer-tofarmer exchange of information to improve performance that can be facilitated by collating and analysing performance data across contexts (Sinclair and Coe 2019) which can be increasingly facilitated through use of mobile phone applications.

Multiple factors contributed to the observed growth differences among the different tree species in various niches: damage by livestock and then sprouting, differences in composting, watering, seedling protection, mixing with other tree species and the like. Growth differences of the shared species between the semi-arid and the sub-humid sites, namely, $C$. africana, G. robusta, J. mimosifolia, L. leucocephala, $M$. stenopetala and $S$. sesban under the different niches showed that the effects of species and niche were significant both on height and dbh. Similarly, significant differences were reported for growth between agroecologies and niches. For example, significant growth difference was reported for $G$. robusta between niches and for Eucalyptus woodlots between agroecologies in Rwanda (Bucagu et al. 2013).

Putting all of the above together, we can see that supporting an increase in tree cover in farm landscapes is more complex than simply planting trees (Holl and Brancalion 2020). A farmer-led approach is required that relates context-specific understanding of farmer species preferences across niches, to availability of seeds and seedlings and appropriate management to ensure their survival and growth (Fig. 7). The grey arrow represents the trajectory of desired tree cover change, based on the general understanding that in much of Ethiopia as elsewhere in Africa, an increase in tree cover and diversity in farm landscapes is needed for both environmental and livelihood reasons. There are filters along the route of tree cover change that modify what is possible. First, farmers priorities must be recognised and understood because they will not plant and manage trees that they do not value. There are then filters of supply of suitable planting material and then what is required for it to survive and grow. These will all be influenced by prevailing policies, the biophysical environment and management. They will also be influenced by farmers' experiences. For example, it is unlikely that farmers will continue to give high priority to growing a species in a niche if their experience suggests it is unlikely to perform well. In terms of this framework, the data we have presented reveals two key points. First, these filters each tend to limit the species and niche diversity resulting from initiatives to increase tree cover. While farmers prioritise many species, this is still a small fraction of possible species for that environment, and a small fraction of those present in natural vegetation. Supplying planting material for preferred species is challenging and will be more so when working at larger scale. Limited survival and growth further reduce the actual diversity of new trees. Secondly, there is variation in what 'passes' each of the filters. This means that there are potential opportunities for increasing the realised diversity of new trees by identifying and replicating good practice from where higher diversity passes through each filter. It is clear 
that if in some cases it is possible to supply and grow a species, then understanding the factors involved in that success should make it easier to repeat it in future.

\section{Conclusion}

This research has shown that there is diversity in the tree species preferred by farmers for planting and in the niches in which they want to plant them. It has also outlined the challenges involved in meeting farmer's tree planting priorities. It was found out that farmers need a high diversity of tree species, that is much higher than that typically available in nurseries. A farmer-led approach to increasing tree cover is proposed to address this that starts with understanding farmers' tree species priorities for different niches and then promoting the tree diversity needed to fulfill this demand as the bedrock of any scaling up activity. Significant differences in tree survival were found among species, farms, agroecologies and niches. The high variation amongst farmers in survival indicates a need to elaborate the impact of local-level risk factors and how they are successfully addressed by some farmers, so that good practice can be identified and shared.

Efforts to increase tree cover in agricultural landscapes should shift from one that simply aims to increase tree numbers, to one aimed at meeting farmer demand for tree diversity. This will require a more nuanced and information-intensive approach. It will also need high investment on each single tree in post planting management to guarantee success and increasing tree diversity. That is more likely to be achieved through an approach of steady, regular and continuous planting and care of a few trees each season rather than large campaigns where farmers plant large numbers of trees at one time.

There are three main strategies of tree seedling production in Ethiopia at present: (1) centralised nurseries run by government or non-governmental organisations (NGOs); (2) cooperatives or group nurseries; and, (3) privately run or farmer nurseries.
Some commercial nurseries are specialized in producing fruit trees. A duel approach of encouraging more diversity in seedling production in the existing nursery sector while also organizing and building capacity for farmers to produce and market their own seedlings for species that that they cannot get from existing nurseries is warranted. Consecutive training events could be provided to farmers on topics such as tree planting techniques, protection of seedlings and post planting management derived from good practice identified in participatory trials and fostering farmerto-farmer knowledge exchange. Where training is accompanied by monitoring, increasingly enabled by mobile phone applications that farmers can use to contribute performance data for consolidated analysis, co-learning about what tree planting practices work where and for whom can be accelerated.

Acknowledgements We remain grateful to the late Diriba Negusie for his active involvement in the participatory trials. The study is part of the trials funded by the "Trees for Food Security Project" supported by the Australian Centre for International Agricultural Research (ACIAR) and the CGAIR Research Programme on Forests, Trees and Agroforestry (FTA). The farmers and local partners who were collaborative during the survey and the participatory trails are gratefully acknowledged.

Open Access This article is licensed under a Creative Commons Attribution 4.0 International License, which permits use, sharing, adaptation, distribution and reproduction in any medium or format, as long as you give appropriate credit to the original author(s) and the source, provide a link to the Creative Commons licence, and indicate if changes were made. The images or other third party material in this article are included in the article's Creative Commons licence, unless indicated otherwise in a credit line to the material. If material is not included in the article's Creative Commons licence and your intended use is not permitted by statutory regulation or exceeds the permitted use, you will need to obtain permission directly from the copyright holder. To view a copy of this licence, visit http://creativecommons.org/licenses/by/4.0/.

\section{Appendix}

See Table 5 . 


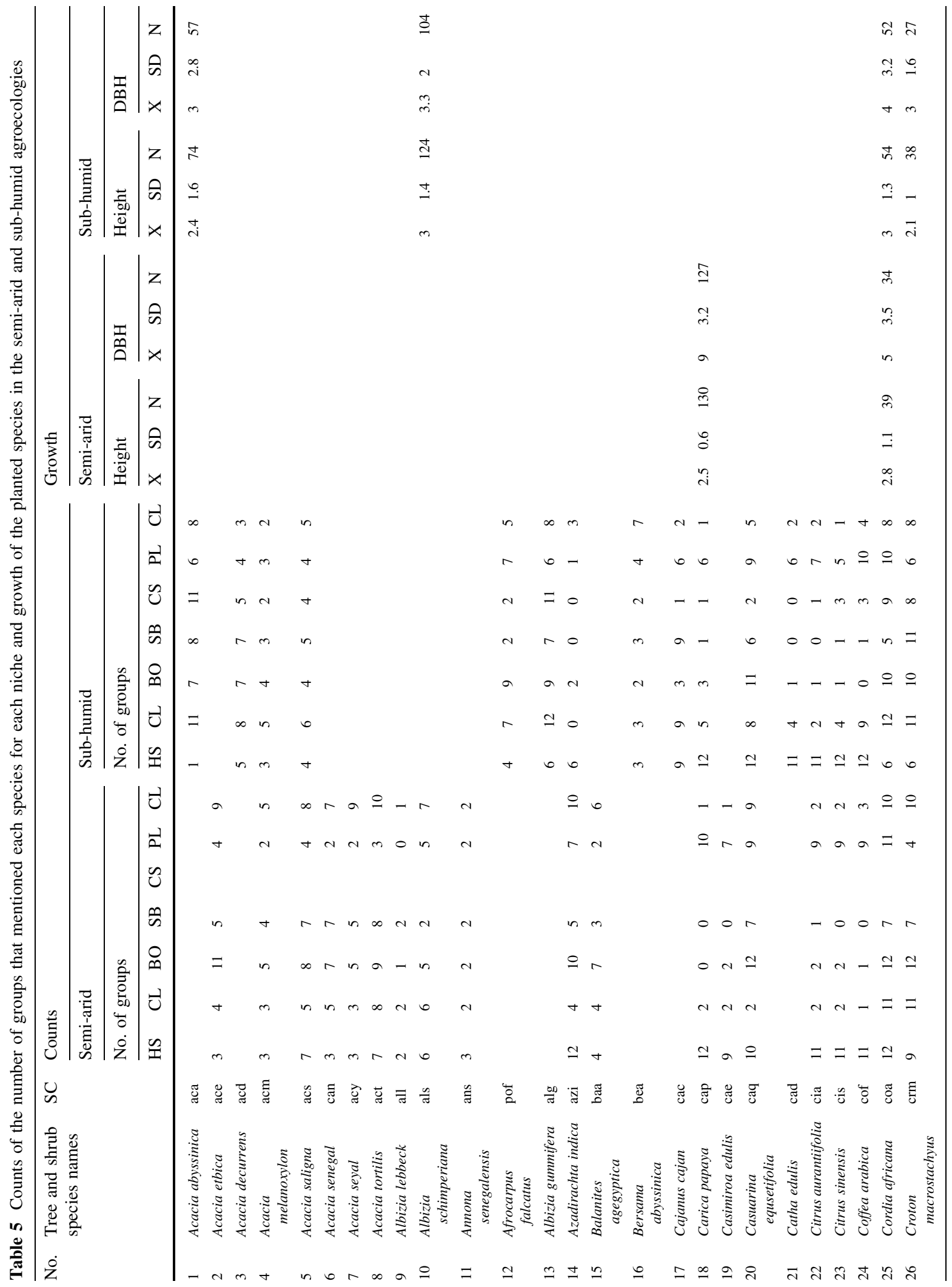




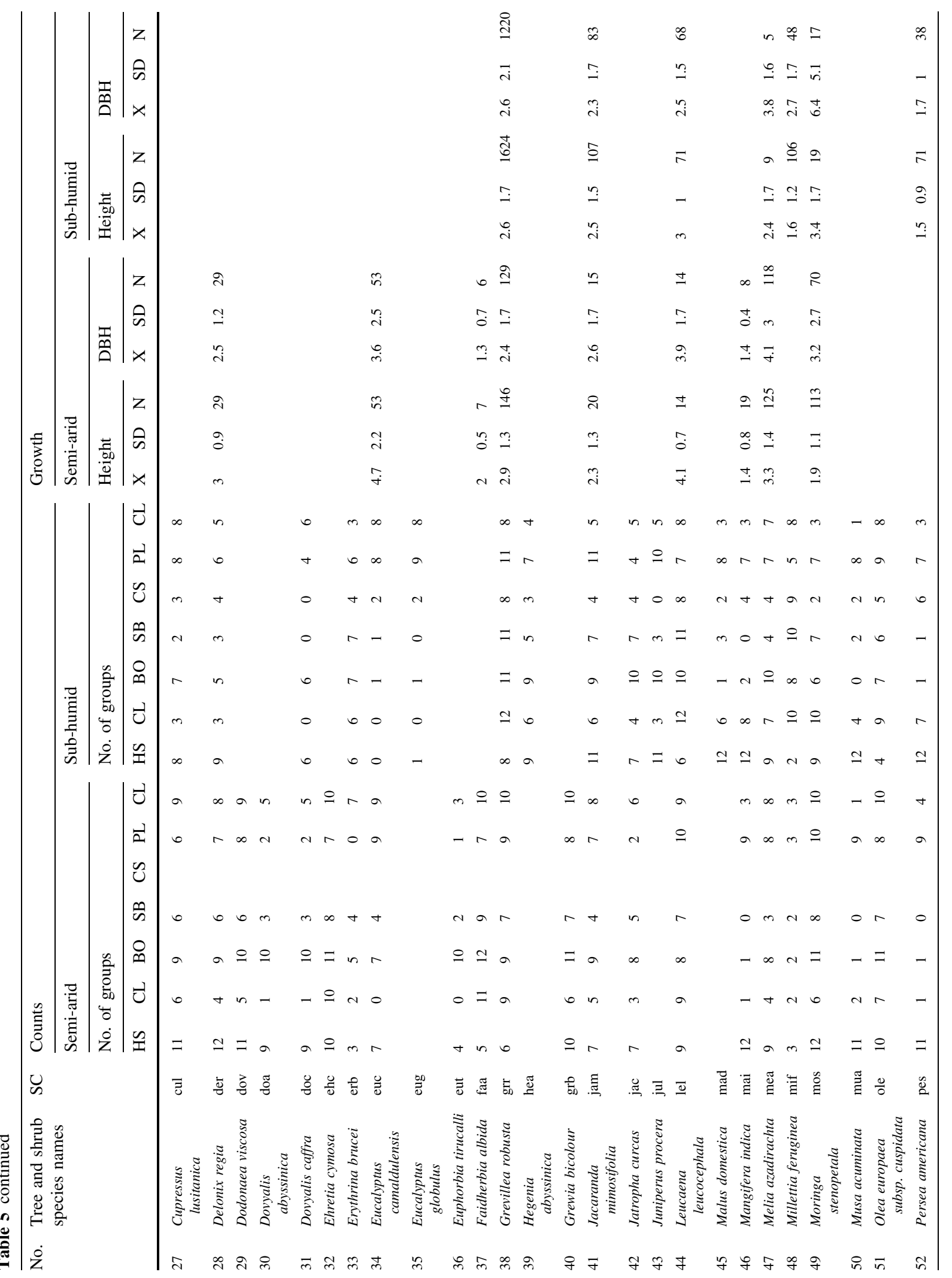




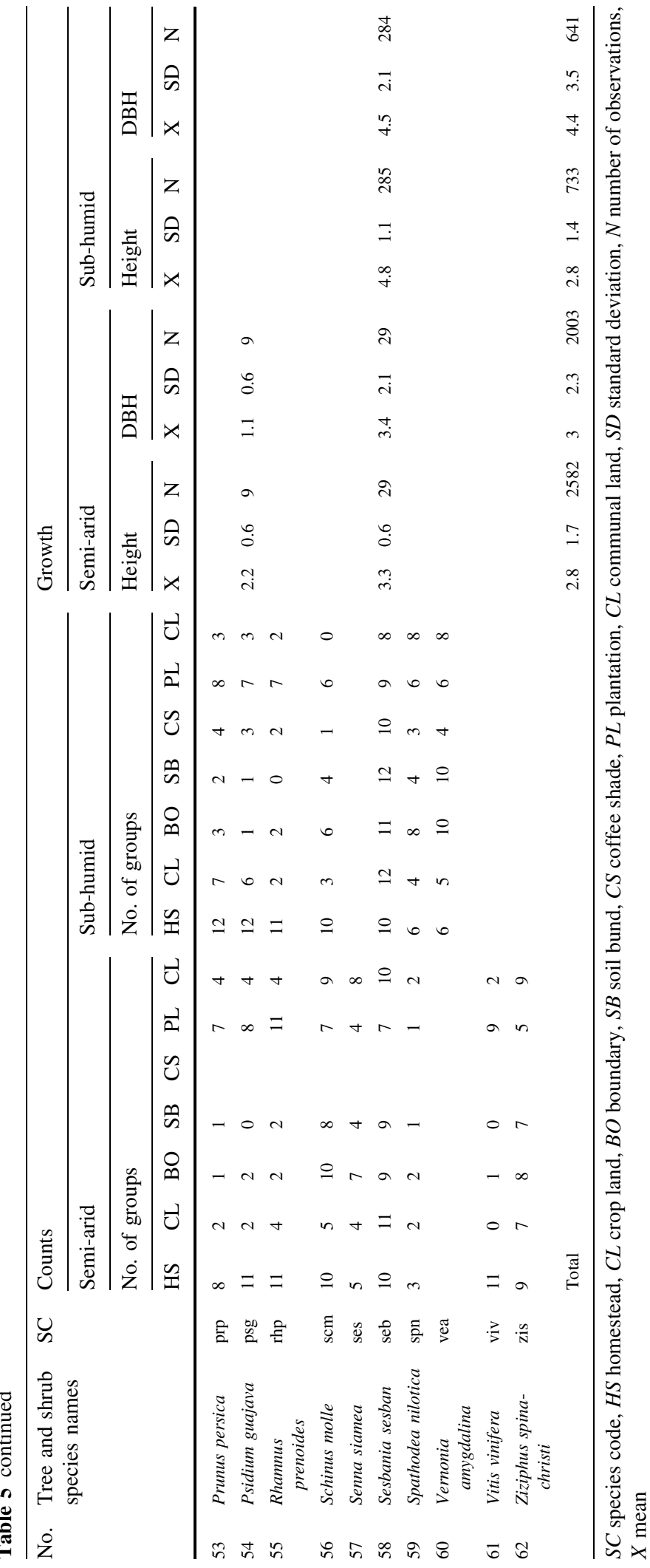




\section{References}

Abebe T (2005) Diversity in homegarden agroforestry systems of Southern Ethiopia

Abebe T, Wiersum K, Bongers F (2010) Spatial and temporal variation in crop diversity in agroforestry homegardens of southern Ethiopia. Agrofor Syst 78:309-322

Akinnifesi FK, Makumba W, Sileshi G, Ajayi OC, Mweta D (2007) Synergistic effect of inorganic N and P fertilizers and organic inputs from Gliricidia sepium on productivity of intercropped maize in Southern Malawi. Plant Soil 294:203-217

Amede T, Taye M (2015) Home garden assessment report: system niches, production and marketing constraints and intensification barriers in the Ethiopian highlands. In: International crops research institute for semiarid tropics (ICRISAT). www.africa-rising.net

Barnes R, Fagg CW (2003) Faidherbia albida: monograph and annotated bibliography. University of Oxford, Oxford

Barrios E, Sileshi GW, Shepherd K, Sinclair F (2012) Agroforestry and soil health: linking trees, soil biota and ecosystem services. In: Wall DH et al (eds) Soil ecology and ecosystem services. Oxford University Press, New York, pp 315-330. https://doi.org/10.1093/acprof:oso/ 9780199575923.001.0001

Barrios E, Valencia V, Jonsson M, Brauman A, Hairiah K, Mortimer PE, Okubo S (2018) Contribution of trees to the conservation of biodiversity and ecosystem services in agricultural landscapes. Int $\mathbf{J}$ Biodivers Sci Ecosyst Serv Manag 14:1-16

Bekele T (2005) Recruitment, survival and growth of Olea europaea subsp. cuspidata seedlings and juveniles in dry Afromontane forests of northern Ethiopia. Trop Ecol 46:113-126

Bell T, Freckleton RP, Lewis OT (2006) Plant pathogens drive density-dependent seedling mortality in a tropical tree. Ecol Lett 9:569-574

Benayas JMR, Bullock JM (2012) Restoration of biodiversity and ecosystem services on agricultural land. Ecosystems 15:883-899

Boerner RE, Brinkman JA (1996) Ten years of tree seedling establishment and mortality in an Ohio deciduous forest complex. Bull Torrey Bot Club 123:309-317. https://doi. org/10.2307/2996780

Boffa J-M, Turyomurugyendo L, Barnekow-Lillesø J-P, Kindt $\mathrm{R}$ (2005) Enhancing farm tree diversity as a means of conserving landscape-based biodiversity. Mt Res Dev 25:212-217

Bucagu C, Vanlauwe B, Van Wijk M, Giller KE (2013) Assessing farmers' interest in agroforestry in two contrasting agro-ecological zones of Rwanda. Agrofor Syst 87:141-158

Carroll Z, Bird S, Emmett B, Reynolds B, Sinclair F (2004) Can tree shelterbelts on agricultural land reduce flood risk? Soil Use Manag 20:357-359

Chirwa PW, Ong CK, Maghembe J, Black CR (2007) Soil water dynamics in cropping systems containing Gliricidia sepium, pigeonpea and maize in southern Malawi. Agrofor Syst 69:29-43
Coe R, Sinclair F, Barrios E (2014) Scaling up agroforestry requires research 'in' rather than 'for' development. Curr Opin Environ Sustain 6:73-77

Coe R, Hughes K, Sola P, Sinclair F (2017) Planned comparisons demystified. World Agroforestry Centre, Nairobi. http://dx.doi.org/10.5716/WP17354.PDF

Dawson IK, Lengkeek A, Weber JC, Jamnadass R (2009) Managing genetic variation in tropical trees: linking knowledge with action in agroforestry ecosystems for improved conservation and enhanced livelihoods. Biodivers Conserv 18:969

De Beenhouwer M, Geeraert L, Mertens J, Van Geel M, Aerts R, Vanderhaegen K, Honnay O (2016) Biodiversity and carbon storage co-benefits of coffee agroforestry across a gradient of increasing management intensity in the SW Ethiopian highlands. Agric Ecosyst Environ 222:193-199

Dedefo K, Derero A, Tesfaye Y, Muriuki J (2017) Tree nursery and seed procurement characteristics influence on seedling quality in Oromia, Ethiopia Forests. Trees Livelihoods 26:96-110

Derero A, Gailing O, Finkeldey R (2011) Maintenance of genetic diversity in Cordia africana Lam. a declining forest tree species in Ethiopia. Tree Genet Genomes 7:1-9

Desta S, Coppock DL (2002) Cattle population dynamics in the southern Ethiopian rangelands, 1980-1997. J Range Manag 55:439-451

Duguma LA, Atela J, Minang PA, Ayana AN, Gizachew B, Nzyoka JM, Bernard F (2019) Deforestation and forest degradation as an environmental behavior: unpacking realities shaping community actions land 8:26

Dumont ES, Gnahoua G-M, Ohouo L, Sinclair FL, Vaast P (2014) Farmers in Côte d'Ivoire value integrating tree diversity in cocoa for the provision of ecosystem services. Agrofor Syst 88:1047-1066

Dumont ES, Bonhomme S, Pagella TF, Sinclair FL (2019a) Structured stakeholder engagement leads to development of more diverse and inclusive agroforestry options. Exp Agric 55:252-274

Dumont ES, Gassner A, Agaba G, Nansamba R, Sinclair F (2019b) The utility of farmer ranking of tree attributes for selecting companion trees in coffee production systems. Agrofor Syst 93:1469-1483

EFAP (1994) Ethiopian forestry action program: final report. Ministry of Natural Resources Development and Environmental Protection, Addis Ababa

Endale Y, Derero A, Argaw M, Muthuri C (2017) Farmland tree species diversity and spatial distribution pattern in semiarid East Shewa, Ethiopia Forests. Trees Livelihoods 26:199-214

German LA, Kidane B, Shemdoe R (2006) Social and environmental trade-offs in tree species selection: a methodology for identifying niche incompatibilities in agroforestry. Springer, New York

Getahun A (2003) Eucalyptus farming in Ethiopia: the case for eucalyptus woodlots in the Amhara region. In: Amede T (ed) Natural resources degradation and environmental concerns in the Ainhara National Regional State: impact on food security. Proceedings of the natural resource management conference, July 24-26, 2002, Bahir Dar, Ethiopia. Ethiopian Society of Soil Science, pp 137-153 
Harrison RD, Thierfelder C, Baudron F, Chinwada P, Midega C, Schaffner U, Van Den Berg J (2019) Agro-ecological options for fall armyworm (Spodoptera frugiperda JE Smith) management: providing low-cost, smallholder friendly solutions to an invasive pest. J Environ Manag 243:318-330

Harvey CA et al (2006) Patterns of animal diversity in different forms of tree cover in agricultural landscapes. Ecol Appl 16:1986-1999

Holl KD, Brancalion PH (2020) Tree planting is not a simple solution. Science 368:580-581

Iiyama M et al (2017) Understanding patterns of tree adoption on farms in semi-arid and sub-humid Ethiopia. Agrofor Syst 91:271-293

Ilstedt U, Malmer A, Verbeeten E, Murdiyarso D (2007) The effect of afforestation on water infiltration in the tropics: a systematic review and meta-analysis. For Ecol Manag 251:45-51

Jagger P, Pender J, Gebremedhin B (2005) Trading off environmental sustainability for empowerment and income: woodlot devolution in northern Ethiopia. World Dev 33:1491-1510

Jose S (2009) Agroforestry for ecosystem services and environmental benefits: an overview. Agrofor Syst 76:1-10

Kassa H, Gebrehiwet K, Yamoah C (2010) Balanites aegyptiaca, a potential tree for parkland agroforestry systems with sorghum in Northern Ethiopia. J Soil Sci Environ Manag 1:107-114

Kidanu S, Mamo T, Stroosnijder L (2005) Biomass production of Eucalyptus boundary plantations and their effect on crop productivity on Ethiopian highland Vertisols. Agrofor Syst 63:281-290

Kuyah S et al (2016) Trees in agricultural landscapes enhance provision of ecosystem services in Sub-Saharan Africa. Int J Biodivers Sci Ecosyst Serv Manag 12:255-273

Lemenih M, Kassa H (2014) Re-greening Ethiopia: history, challenges and lessons. Forests 5:1896-1909

Lilles $\emptyset$ J-PB, Derero A (2019) Provision of adequate tree seed porttfolios' (PATSPO project)—consultancy on a tree seed sub-sector assessment. PATSPO/ICRAF OFFICE, Addis Ababa

Lilles $\emptyset$ J-PB et al (2018) Why institutional environments for agroforestry seed systems matter. Dev Policy Rev 36:O89$\mathrm{O} 112$

Makumba W, Akinnifesi FK, Janssen B, Oenema O (2007) Long-term impact of a gliricidia-maize intercropping system on carbon sequestration in southern Malawi. Agric Ecosyst Environ 118:237-243

Nyaga J, Barrios E, Muthuri C, Öborn I, Matiru V, Sinclair F (2015) Evaluating factors influencing heterogeneity in agroforestry adoption and practices within smallholder farms in Rift Valley, Kenya. Agric Ecosyst Environ 212:106-118
Nyoka BI et al (2015) Tree seed and seedling supply systems: a review of the Asia, Africa and Latin America models Small-scale. Forestry 14:171-191

Poschen P (1986) An evaluation of the Acacia albida-based agroforestry practices in the Hararghe highlands of Eastern Ethiopia. Agrofor Syst 4:129-143

Reubens B et al (2009) Establishment and management of woody seedlings in gullies in a semi-arid environment (Tigray, Ethiopia). Plant Soil 324:131

Samuel D, Derero A, Kebebew Z, Hadgu KM (2019) Tree species diversity and spatial distribution patterns on agricultural landscapes in sub-humid Oromia, Ethiopia. Agrofor Syst 93:1015-1029

Sanou J, Zougmoré R, Bayala J, Teklehaimanot Z (2010) Soil infiltrability and water content as affected by Baobab (Adansonia digitata L.) and Néré (Parkia biglobosa (Jacq.) Benth) trees in farmed parklands of West Africa. Soil Use Manag 26:75-81

Sinclair F, Coe R (2019) The options by context approach: a paradigm shift in agronomy. Exp Agric 55:1-13

Sinclair F, Wezel A, Mbow C, Chomba S, Robiglio V, Harrison R (2019) The contribution of agroecological approaches to realizing climate-resilient agriculture GCA: Rotterdam, The Netherlands

Steenwerth KL et al (2014) Climate-smart agriculture global research agenda: scientific basis for action. Agric Food Secur 3:11

Taddese G (2001) Land degradation: a challenge to Ethiopia. Environ Manag 27:815-824

Teketay D (2001) Deforestation, wood famine, and environmental degradation in Ethiopia's highland ecosystems: urgent need for action Northeast African. Studies 8:53-76

Teshome DS (2014) Assessment of tree species diversity patterns and socioeconomic uses on agricultural landscapes a case of Western Oromia, Ethiopia, p 107

Tsegaye D, Moe SR, Vedeld P, Aynekulu E (2010) Land-use/cover dynamics in Northern Afar rangelands, Ethiopia. Agric Ecosyst Environ 139:174-180

van Noordwijk M, Coe R, Sinclair FL (2019) Agroforestry paradigms. In: van Noordwijk M (ed) Sustainable development through trees on farms: Agroforestry in its fifth decade. World Agroforestry (ICRAF) Southeast Asia Regional Program, Bogor, Indonesia, pp 1-14

Weibull A-C, Östman Ö, Granqvist Å (2003) Species richness in agroecosystems: the effect of landscape, habitat and farm management. Biodivers Conserv 12:1335-1355

Zomer RJ et al (2016) Global tree cover and biomass carbon on agricultural land: the contribution of agroforestry to global and national carbon budgets. Sci Rep 6:29987. https://doi. org/10.1038/srep29987

Publisher's Note Springer Nature remains neutral with regard to jurisdictional claims in published maps and institutional affiliations. 